\title{
Cardiovascular assessment in horses sedated with xylazine or amitraz
}

\author{
[Avaliação cardiovascular em eqüinos sedados com xilazina ou amitraz] \\ R.L. Linardi ${ }^{1}$, J.C. Canola $^{2}$, C.A.A. Valadão ${ }^{2}$ \\ ${ }^{1}$ Aluno de pós-graduação - FCAV-UNESP- Jaboticabal, SP \\ ${ }^{2}$ Faculdade de Ciências Agrárias e Veterinária - UNESP- Jaboticabal, SP
}

\begin{abstract}
Cardiovascular effects due to intravenous (IV) xylazine $(1.0 \mathrm{mg} / \mathrm{kg})$ or amitraz $(0.1$ or $0.4 \mathrm{mg} / \mathrm{kg})$ were evaluated in horses. Left ventricular function indexes, heart rate (HR), and cardiac output (CO) were measured by echocardiography. Second degree atrioventricular (AV) block was detected by electrocardiography. Invasive arterial blood pressure (AP) was also evaluated. All parameters were measured immediately before and during 60 minutes after drug injection. $\mathrm{HR}, \mathrm{CO}$, and second degree AV block were different between xylazine and amitraz- $0.4 \mathrm{mg} / \mathrm{kg}$ groups. Xylazine induced initial hypertension 10 minutes after injection, and hypotension was observed 30 minutes after amitraz$0.4 \mathrm{mg} / \mathrm{kg}$ administration. Except for the second degree AV block which occurred only at five minutes, there was no change in the echocardiographic measurements after administration of amitraz- $0.1 \mathrm{mg} / \mathrm{kg}$. Thus, amitraz- $0.4 \mathrm{mg} / \mathrm{kg}$ and xylazine $(1.0 \mathrm{mg} / \mathrm{kg})$ induced similar cardiovascular side effects, but longlasting action of amitraz- $0.4 \mathrm{mg} / \mathrm{kg}$ in the cardiovascular system was observed.
\end{abstract}

Keywords: horse, alpha-2 agonist, xylazine, amitraz, echocardiography

\section{RESUMO}

Avaliaram-se efeitos cardiovasculares decorrentes da administração intravenosa (IV) de xilazina $(1,0 \mathrm{mg} / \mathrm{kg})$ ou amitraz $(0,1 \mathrm{ou} 0,4 \mathrm{mg} / \mathrm{kg})$ em cavalos. Os indices ventriculares, a freqüência cardíaca (FC) e o débito cardíaco (DC) foram mensurados por ecocardiografia, e o bloqueio atrioventricular de segundo grau (BAV2), detectado por eletrocardiografia. A pressão arterial invasiva foi também avaliada. Todos os parâmetros foram mensurados imediatamente antes e durante 60 minutos após a administração dos fármacos. Os valores da $F C$, do DC e do BAV2 apresentaram alterações significativas nos grupos da xilazina e do amitraz na dose de 0,4mg/kg. A xilazina induziu hipertensão inicial 10 minutos após sua administração e a dose de $0,4 \mathrm{mg} / \mathrm{kg}$ amitraz induziu hipotensão após 30 minutos. Exceto pela ocorrência de BAV2 aos cinco minutos, não houve alteração nas mensurações ecocardiográficas após a administração de amitraz-0.1mg/kg. Nas doses utilizadas, a xilazina $(1,0 \mathrm{mg} / \mathrm{kg})$ e o amitraz-0,4mg/kg promoveram alterações semelhantes no sistema cardiovascular, porém os efeitos cardiovasculares provocados pelo amitraz foram mais prolongados.

Palavras-chave: eqüino, agonista alfa-2, xilazina, amitraz, ecocardiografia

\section{INTRODUCTION}

Cardiac ultrasound also named echocardiography was first used in veterinary medicine by Pippers and Hamlin (1977). Echocardiography is able to determine cardiovascular effects drugs-induced and to establish the compromised degree of cardiac function, allowing inferring about the efficacy, safety, and viability of drugs and their possible procedure risks (Raisis et al., 2000; 2005).

Considered a safe, simple, and noninvasive method of anatomical and functional evaluation

Recebido em 23 de junho de 2006

Aceito em 10 de janeiro de 2008

E-mail: rlinardi@vetmed.lsu.edu 
of the heart, the echocardiographic exam has been strongly employed in equine clinics for assessment of cardiac performance (Reef, 1995; Young and Scott, 1998). Besides some limitations, Kriz and Rose (2002) stated that Mmode, B-mode, and Doppler echocardiography are the only non-invasive tools to accurately measure cardiac dimensions and indexes of cardiac function, and they have been used to assess the effects of training or drugs on cardiac size and performance.

Although the cardiac output measure is not so accurate with the transthoracic echocardiography compared to other invasive methods and the ejection, fraction, and shortening fractional are cardiac function parameters and not a contractility parameters, both cardiac output and left ventricular function may be used to infer about the systolic function (Young and Scott, 1998; Canola et al., 2002).

Adrenergic receptor alpha-2 agonists are considered excellent sedatives usually used in association to potency other drugs (England and Clarke, 1996); nevertheless, they can cause light to severe cardiovascular changes and compromise the systemic hemodynamic (Bonagura and Muir, 1991; Canola et al., 2002; Pereira, 2002). An initial and transitory hypertension xylazine-induced is described in the literature followed by mild and prolonged hypotension and bradicardia reflex (negative cronotropism) which are usually followed by a second degree atrioventricular block and a decrease of 30 to $50 \%$ in CO (Bonagura and Muir, 1991; England and Clarke, 1996; QueirózNeto et al., 2000; Canola et al., 2002; Pereira, 2002; Farias, 2004).

Amitraz [N-methyl-N'-2,4-xylyl-N-(N-2,4xylylformimidyl) formamidine] is an acaricidal formamidine widely used in the control of ectoparasites in veterinary medicine (Bueno-deCamargo et al., 1999; Spinosa et al., 2002). Although its action is not completely understood, amitraz is considered an adrenergic receptor alpha-2 agonist by exhibiting similar sedative proprieties (Queiroz-Neto et al., 1998; 2000; Bueno-de-Camargo et al., 1999; Farias, 2004; Mendes et al., 2007). The topical use of amitraz is contraindicated in horses due to a reduction in the intestinal motility and a promotion of large colon impaction (Oliveira et al., 2003). However, some authors published that the intravenous (IV) administration of amitraz in dogs and horses induced similar clinical effects compared to the administration of alpha-2 agonists, when amitraz was used in proper doses and diluted vehicles (Queiroz-Neto et al., 2000; Farias, 2004; Mendes et al., 2007).

The objectives of this study were to evaluate and compare the cardiovascular changes of the intravenous administration of 0.1 and $0.4 \mathrm{mg} / \mathrm{kg}$ amitraz and $1.0 \mathrm{mg} / \mathrm{kg}$ xylazine in horses using a noninvasive echocardiographic method.

\section{MATERIAL AND METHODS}

Eight healthy adult Mangalarga Paulista horses aging from six to 10-year-old and weighing from 325 to $450 \mathrm{~kg}$ (mean $385 \mathrm{~kg}$ ) were studied. The animals were fasted six hours prior to the experiment. All procedures and evaluations were conducted in a closed and temperature controlled $\left(25^{\circ} \mathrm{C}\right)$ room. All horses randomly received three treatments (Ta1, Ta2, and $\mathrm{Tx}), 0.1$ or $0.4 \mathrm{mg} / \mathrm{kg}$ of amitraz ${ }^{1}$ diluted in lipid vehicle (Ta1 or Ta2) or $1.0 \mathrm{mg} / \mathrm{kg}$ of xylazine ${ }^{2}$ (Tx) by intravenous via (IV). Drugs were administered at time intervals not less than 15 days (washout period).

To evaluate the cardiovascular system effects, left ventricular function [fractional shortening $(\% \mathrm{FS})$ and ejection fraction $(\% \mathrm{FE})]$, heart rate (HR), and cardiac output (CO) were measured by the standard (transthoracic) echocardiography ${ }^{3}$. The exam was performed in the right hemithorax (parasternal region), dorsal to the olecranon where the $3.5 \mathrm{MHz}$ probe was placed in the $4^{\text {th }}$ or $5^{\text {th }}$ intercostal space in order to obtain the best cardiac window.

Two-dimensional (2-D) or B-mode image was primarily used to access the heart in its longitudinal and transversal axis to observe all four chambers and to locate papillary muscles and chordae tendineae, respectively. The $\mathrm{M}$ mode view was then used to measure the cardiac

${ }^{1}$ Amitraz - Cristália Produtos Químicos e Farmacêuticos Ltda. - Itapira, Brazil.

${ }^{2}$ Sedomin ${ }^{\circledR}$ - Laboratórios KÖNIG do Brasil Ltda. S.A - São Paulo, Brazil.

${ }^{3}$ PIE MEDICAL-SCANNER 200 VET - Maastricht -

Holland. Trademark: Nutricell - Campinas, Brazil. - 
dimensions of the left ventricle such as interventricular septal thickness, left ventricular (LV) diameter, and LV thickness in the systolic and diastolic phases. These measures were used by the software program using the Teicholz method to automatically calculate the ventricular function and $\mathrm{CO}$ value as well.

The HR was determined by the ultrasound machine, measuring the distance between two non-consecutives systoles using the M-mode view. The mean invasive arterial blood pressure (MAP) was evaluated in the carotid artery by electrocardiography ${ }^{4}$ using a multiparametric monitor ${ }^{5}$; and the base-apex method with aVL lead, $25 \mathrm{~mm} / \mathrm{s}$ of speed and $2 \mathrm{~N}$ of sensibility. The occurrence of second degree AV block was observed by both echocardiography and eletrocardiography. All parameters were measured immediately before (M0 - basal) and after the treatments, every five minutes during the first 20 minutes (M5, M10, M15, and M20), and every 10 minutes to complete 60 minutes of total evaluation period (M30, M40, M50, and M60).

Data were analyzed by the statistical program SAS $^{6}$ using Shapiro-Wilk as a normality test and Tukey test for means comparison. Difference were considered significant at $\mathrm{P}<0.05$.

\section{RESULTS AND DISCUSSION}

The dose of $0.1 \mathrm{mg} / \mathrm{kg}$ of amitraz used in this experiment was based on previous studies (Queiróz-Neto et al., 1998; 2000). However, no information was found in the literature regarding the dose of amitraz for horses when it is diluted in lipid vehicle; therefore, the higher dose of amitraz $(0.4 \mathrm{mg} / \mathrm{kg})$ was obtained by alommetry extrapolation (Pachaly and Brito, 2001) using the known dose $0.1 \mathrm{mg} / \mathrm{kg}$ of amitraz in dogs reported by Farias (2004).

Left ventricular functions indexes (FE and FS), $\mathrm{HR}, \mathrm{CO}$, and MAP values are presented in Table 1 and second degree AV block in Table 2.

\footnotetext{
${ }^{4}$ TEB - Mod. ECGPC software version 1.10 - Comercial Vidmed Ltda. - Ribeirão Preto, Brazil.

${ }^{5}$ DIGIMAX 5000 - Digicare Tecnologia Biomédica Ltda. Rio de Janeiro, Brazil.

${ }^{6}$ Statistical analyses system - SAS - Realease 8,02 TS level 02MO . Licensed to UNESP
}

Amitraz-0.1mg/kg diluted in lipid vehicle did not show significant cardiovascular side effects except for the presence of a second degree AV block only at five minutes after the administration of the drug. This lower dose of amitraz did not show similar alpha-2 agonists sedative effects as well. On the contrary, based on the literature, other studies demonstrated that the same dose of amitraz, but in different dilutions, was able to induce significant cardiovascular changes and sedative effects in horses (Harkins et al., 1997; Queiroz-Neto et al., $1998 ; 2000)$. In this study, the dose of $0.1 \mathrm{mg} / \mathrm{kg}$ of amitraz, IV administered, was probably insufficient to produce plasma level high enough to bind alpha-2 receptors and induce their characteristic cardiovascular effects. Possibly, the lipid diluent interfered with the drug release due to the high affinity between the drug and the diluent used. Thurmon et al. (1996) stated that all drug effects are related to the dose, via, time of injection, and diluent used as well. The lipid vehicle used to dilute amitraz in this study was previously considered free of pharmacological properties. It was demonstrated that this vehicle did not compromise the cardiovascular system and it did guarantee the fidelity of the actions of amitraz when it was IV administered in dogs (Farias, 2004).

Horses that received amitraz- $0.4 \mathrm{mg} / \mathrm{kg}$ showed similar effects on cardiovascular system compared to alpha- 2 agonists drugs, such as HR and $\mathrm{CO}$ decrease, and MAP oscillations; however, except for the HR, amitraz induced longer-lasting cardiovascular effects (up to 60 minutes) compared to xylazine-induced effects. Both xylazine and amitraz- $0.4 \mathrm{mg} / \mathrm{kg}$ decreased HR values during 60 minutes after injection. Possibly, the significant decrease of HR and consequent decrease of $\mathrm{CO}$ were due to the decrease of sympathetic activity by alpha- 2 agonist action in the central nervous system (CNS) in horses. Comparing both doses of amitraz used in this study, the HR decrease appears to be dose-dependent and influence the $\mathrm{CO}$ as shown in other studies. The group that received amitraz- $0.4 \mathrm{mg} / \mathrm{kg}$ had a reduction in approximately $43 \%$ in the $\mathrm{CO}$ during the 60 minutes following the IV administration, while the $\mathrm{CO}$ decreased $45 \%$ at five minutes, and $38 \%$ at 10 minutes after xylazine IV injection. The HR may be also mediated in part by the barorreceptor vagal reflex hypertension response 
(reflex bradicardia), leading to a CO decrease (Patteson, 1996) as seen with the xylazine group in this study. The xylazine-induced hypertension lasted only for the first five minutes after its injection and then returned to basal values. Differently from xylazine, the amitraz- $0.4 \mathrm{mg} / \mathrm{kg}$ induced hypotension, from 30 to 60 minutes after
IV administration without initial hypertension, probably occurred due to a slower drug disposition caused by the lipid diluent. Corroborating with Farias (2004), these results concluded that the bradicardia induced by amitraz was predominantly mediated by the CNS.

Table 1. Mean values and $\pm \mathrm{SD}$ of echocardiographic cardiac (heart rate $-\mathrm{HR}$, cardiac output $-\mathrm{CO}$, ejection fraction $-\mathrm{FE}$, and fractional shortening $-\mathrm{FS}$ ) and mean arterial blood pressure (MAP) measured before (0) and after amitraz (Ta1: $0.1 \mathrm{mg} / \mathrm{kg}$ or Ta2: $0.4 \mathrm{mg} / \mathrm{kg}$ ) or xylazine (Tx: $1.0 \mathrm{mg} / \mathrm{kg}) \mathrm{IV}$ in eight clinically normal horses during 60 minutes (five to 60 minutes)

\begin{tabular}{|c|c|c|c|c|c|c|c|c|c|c|}
\hline & & & & & Time (mi & nutes) & & & & \\
\hline & & 0 & 5 & 10 & 15 & 20 & 30 & 40 & 50 & 60 \\
\hline & Ta1 & $38 \pm 3$ & $35 \pm 2$ & $32 \pm 0.8$ & $36 \pm 5$ & $33 \pm 4$ & $37 \pm 6$ & $35 \pm 6$ & $33 \pm 4$ & $34 \pm 3$ \\
\hline HR & $\mathrm{Ta} 2$ & $45 \pm 2 \mathrm{~A}$ & $35 \pm 1 B$ & $34 \pm 1 B$ & $33 \pm 0.6 \mathrm{~B}$ & $33 \pm 2 B$ & $33 \pm 1 B$ & $33 \pm 1 B$ & $34 \pm 1 B$ & $36 \pm 2 \mathrm{~B}$ \\
\hline (bpm) & Tx & $43 \pm 2 \mathrm{~A}$ & $30 \pm 2 \mathrm{~B}$ & $30 \pm 1 \mathrm{~B}$ & $31 \pm 2 \mathrm{~B}$ & $34 \pm 3 \mathrm{AB}$ & $33 \pm 3 \mathrm{~B}$ & $31 \pm 3 \mathrm{~B}$ & $35 \pm 3 \mathrm{AB}$ & $33 \pm 3 \mathrm{~B}$ \\
\hline & Ta1 & $8 \pm 0.5$ & $7 \pm 1$ & $7 \pm 2$ & $9 \pm 2$ & $8 \pm 1$ & $8 \pm 2$ & $8 \pm 2$ & $8 \pm 1$ & $9 \pm 1$ \\
\hline $\mathrm{CO}$ & $\mathrm{Ta} 2$ & $12 \pm 2 \mathrm{~A}$ & $7 \pm 0.7 \mathrm{~B}$ & $7 \pm 1 \mathrm{~B}$ & $7 \pm 0.6 \mathrm{~B}$ & $6 \pm 0.4 \mathrm{~B}$ & $7 \pm 0.8 \mathrm{~B}$ & $8 \pm 0.8 \mathrm{~B}$ & $7 \pm 0.7 \mathrm{~B}$ & $7 \pm 0.6 \mathrm{~B}$ \\
\hline (1/min.) & Tx & $10 \pm 1 \mathrm{~A}$ & $6 \pm 0.8 \mathrm{~B}$ & $6 \pm 1 \mathrm{~B}$ & $7 \pm 1 \mathrm{AB}$ & $8 \pm 1 \mathrm{AB}$ & $8 \pm 0.8 \mathrm{AB}$ & $8 \pm 1 \mathrm{AB}$ & $10 \pm 1 \mathrm{AB}$ & $9 \pm 0.6 \mathrm{AB}$ \\
\hline & Ta1 & $72 \pm 4$ & $74 \pm 4$ & $68 \pm 1$ & $66 \pm 2$ & $70 \pm 4$ & $69 \pm 5$ & $66 \pm 2$ & $71 \pm 3$ & $68 \pm 2$ \\
\hline $\mathrm{FE}$ & $\mathrm{Ta} 2$ & $70 \pm 4$ & $64 \pm 3$ & $64 \pm 3$ & $65 \pm 3$ & $58 \pm 3$ & $66 \pm 3$ & $69 \pm 3$ & $64 \pm 3$ & $65 \pm 3$ \\
\hline$(\%)$ & Tx & $64 \pm 3$ & $60 \pm 8$ & $63 \pm 5$ & $60 \pm 3$ & $62 \pm 3$ & $62 \pm 5$ & $64 \pm 4$ & $65 \pm 1$ & $63 \pm 2$ \\
\hline & Ta1 & $43 \pm 3$ & $44 \pm 4$ & $40 \pm 1$ & $38 \pm 1$ & $45 \pm 5 a$ & $41 \pm 5$ & $38 \pm 2$ & $43 \pm 1$ & $40 \pm 2$ \\
\hline FS & $\mathrm{Ta} 2$ & $42 \pm 3$ & $37 \pm 2$ & $37 \pm 2$ & $37 \pm 2$ & $32 \pm 2 b$ & $38 \pm 2$ & $40 \pm 2$ & $36 \pm 2$ & $37 \pm 2$ \\
\hline$(\%)$ & $\mathrm{Tx}$ & $36 \pm 3$ & $34 \pm 2$ & $36 \pm 4$ & $34 \pm 3$ & $35 \pm 2 \mathrm{ab}$ & $35 \pm 3$ & $37 \pm 3$ & $38 \pm 1$ & $36 \pm 2$ \\
\hline & Ta1 & $100 \pm 7$ & $103 \pm 6$ & $100 \pm 6$ & $100 \pm 8$ & $91 \pm 6$ & $90 \pm 6$ & $90 \pm 8$ & $90 \pm 9$ & $87 \pm 9$ \\
\hline MAP & $\mathrm{Ta} 2$ & $101 \pm 8 \mathrm{~A}$ & $102 \pm 9 \mathrm{AB}$ & $89 \pm 9 \mathrm{AB}$ & $92 \pm 9 \mathrm{AB}$ & $88 \pm 9 \mathrm{AB}$ & $84 \pm 9 B$ & $79 \pm 8 B$ & $75 \pm 9 B$ & $77 \pm 9 \mathrm{~B}$ \\
\hline$(\mathrm{mmHg})$ & $\mathrm{Tx}$ & $98 \pm 10 \mathrm{~A}$ & $118 \pm 10 \mathrm{~B}$ & $112 \pm 11 \mathrm{AB}$ & $110 \pm 9 \mathrm{AB}$ & $107 \pm 10 \mathrm{AB}$ & $105 \pm 10 \mathrm{AB}$ & $103 \pm 9 \mathrm{AB}$ & $94 \pm 8 \mathrm{AB}$ & $96 \pm 9 \mathrm{AB}$ \\
\hline
\end{tabular}

Different capital letters indicate significant differences during the time in each treatment (columns). Different lower case letters indicate significant differences between treatment values (rows) $(\mathrm{P}<0.05$; Tukey test).

Table 2. Percentage of second degree atrioventricular (AV) block occurrence (\%) measured before $(0)$ and after amitraz (Ta1: $0.1 \mathrm{mg} / \mathrm{kg}$ or $\mathrm{Ta} 2: 0.4 \mathrm{mg} / \mathrm{kg}$ ) or xylazine $(\mathrm{Tx}: 1.0 \mathrm{mg} / \mathrm{kg}$ ) intravenous administration in eight clinically normal horses during 60 minutes (five to 60 minutes)

\begin{tabular}{lccccccccc}
\hline \multirow{2}{*}{ Treatments } & \multicolumn{10}{c}{ Moment (minutes) } \\
\cline { 2 - 12 } & 0 & 5 & 10 & 15 & 20 & 30 & 40 & 50 & 60 \\
\hline Ta1 & 0 & 25 & 0 & 0 & 0 & 0 & 0 & 0 & 0 \\
Ta2 & 0 & 25 & 12.5 & 37.5 & 25 & 37.5 & 50 & 25 & 25 \\
Ta3 & 0 & 75 & 12.5 & 12.5 & 25 & 12.5 & 12.5 & 0 & 0 \\
\hline
\end{tabular}

It is already established that the action of alpha- 2 agonists in the cardiovascular center promotes a reduction in the $\mathrm{HR}$, contractility, FE, and FS, resulting in less blood pumped by the heart (CO decrease) (Alves, 1999). However, in this study, there were no statistical differences in the cardiac indexes (FE and FS), values after IV administration of xylazine and amitraz during the entire period of evaluation. These results also were previously evidenced also by echocardiography after IV romifidine administration in horses (Bonagura and Muir, 1991; Canola et al., 2002; Pereira, 2002). The $\mathrm{HR}$ and $\mathrm{CO}$ changes without FE and FS changes may be explained by discreet parasympathetic influence in the cardiac inotropism due to its restricted ventricular innervations (Patteson, 1996; Guyton and Hall, 2001) even with predominant vagal activity under alpha 2 agonists action. 
Second degree AV block is usually associated with bradicardia and it arises following the vagal tonus increase (Queiroz-Neto et al., 2000; Farias, 2004). This heart block disappears with the sympathetic activity increase (England and Clarke, 1996; Canola et al., 2002). In this study, the occurrence of second degree AV block in horses was observed since five minutes after the IV administration of xylazine and both doses of amitraz as shown in the Table 2. Only one horse showed second degree AV heart block after receiving amitraz- $0.1 \mathrm{mg} / \mathrm{kg}$, which was limited to the first five minutes. In the group that received amitraz- $0.4 \mathrm{mg} / \mathrm{kg}$, the second degree AV block shown in Fig. 1, lasted no less than 60 minutes. Xylazine promoted the same heart block in $75 \%$ of the horses in the first five minutes after its administration, which lasted 40 minutes. Because the lipid diluent prolonged the drug remaining into the circulation due to a slow drug release, the dose of $0.4 \mathrm{mg} / \mathrm{kg}$ of amitraz did promote longer sympathetic activity decreasing and prolonging cardiovascular effects.



Figure 1. (A) Echocardiogram in B-mode (left) and M-mode (right) showing an increase in the consecutive systolic ventricular distance; and (B) an eletrocardiographic tracing with a VL lead, speed of $25 \mathrm{~mm} / \mathrm{s}$, and sensitivity of $2 \mathrm{~N}$ showing the QRS complex absence after a $\mathrm{P}$ wave, both representing a second degree AV block in an adult horse after five minutes of the IV of amitraz- $0.4 \mathrm{mg} / \mathrm{kg}$.

\section{CONCLUSIONS}

The echocardiographic exam was a safe, simple, noninvasive, and validated method for cardiac evaluation in equine clinics, although it presents some limitation when compared to other techniques. Such limitations were taken in consideration during the evaluation of the results. In this study, the administration of amitraz and xylazine exhibited similar alpha-2 agonist properties in horses. The therapeutic dosages of xylazine $(1.0 \mathrm{mg} / \mathrm{kg})$ and amitraz- $0.4 \mathrm{mg} / \mathrm{kg}$ diluted in lipid vehicle demonstrated similar induced cardiovascular changes and similar degree of cardiac function compromising. However, the lipid vehicle was responsible for prolonged effects induced by amitraz, inferring a major deleterious effect of amitraz- $0.4 \mathrm{mg} / \mathrm{kg}$ compared to xylazine. Amitraz and an appropriated vehicle of dilution are still under investigation and unlike xylazine, no therapeutic dose has been established for it, so far. However, 
the dose of $0.1 \mathrm{mg} / \mathrm{kg}$ of amitraz diluted in lipid vehicle proved to be a subtherapeutic dose for sedation, since it did not cause any significant effect. More studies are needed to better understand the disposition and effects of amitraz as well as to establish an appropriated or ideal vehicle for dilution in order to justify, at some point, the clinical use of amitraz.

\section{ACKNOWLEDGEMENTS}

The authors thanks to the Conselho Nacional de Desenvolvimento Científico e Tecnológico $\mathrm{CNPq}$ Fundation, Brazil, for supporting this work.

\section{REFERENCES}

ALVES, G.E S. Efeito sedativo da romifidina em muares (Equus asinus caballus) não domados. Cienc. Rural, v.29, p.51-55, 1999.

BONAGURA, J.D., MUIR III, W.W. The Cardiovascular System. In: MUIR, W.W., HUBBELL, J.A.E. (Eds). Equine anesthesia: monitoring and emergency therapy, St. Louis: Mosby Year Book, 1991. p.39-104.

BUENO-DE-CAMARGO, M.H., QUEIROZ-NETO, A., ZAMUR, G. et al. Sedação de Eqüinos através da aplicação de amitraz por aspersão sobre as mucosas nasais. Ars Vet., v.15, p.220-226, 1999.

CANOLA, J.C., CARDENAS, J.J., CANOLA, P.A. Efeito da romifidina sobre as dimensões ecocardiográficas e sobre índices da função cardíaca em eqüinos. Ars Vet., v.18, p.231-237, 2002.

ENGLAND, G.C.W., CLARKE, K.W. Alpha2 adrenoceptor agonists in the horse: a review. Br. Vet. J., v.152, p.641-657, 1996.

FARIAS, A. Efeitos clínicos e farmacológicos do amitraz, 2004. 225f. Tese (Doutorado) - Faculdade de Ciências Agrárias e Veterinárias, Universidade Estadual Paulista, Jaboticabal, SP.

GUYTON, A.C., HALL, J.E. Textbook of medical physiology.10.ed. Philadelphia: W.B.Saunders, 2001. p.96-222.

HARKINS, J.D., QUEIROZ-NETO, A., MUNDY, G.D. et al. Development and characterization of an equine behavior chamber and the effects of amitraz and detomidine on spontaneous locomotor activity. J. Vet. Pharmacol. Therap., v.20, p.396-401, 1997.

KRIZ, N.G., ROSE, R.J. Repeatability of standard transthoracic echocardiographic measurements in horses. Aust. Vet. J., v.80, p.362-370, 2002.
MENDES, M.C.; REIS, R.G.; VALADÃO, C.A.A. et al. Comparison of behavioral and clinical effects of intravenous amitraz romifidine administration in horses. Arq. Bras. Med. Vet. Zootec., v.59, p.1433-1438, 2007.

OLIVEIRA, K.J.D., ROIER, E.C.R., BOTTEON, P.T.L. Intoxicação por amitraz em eqüinos atendidos no Hospital Veterinário da UFRural RJ. Rev. Unv. Rural - Série Cienc. Vida, v.23, p185-186, 2003.

PACHALY, J.R., BRITO, H.F.V. Interspecific allometric scaling. In: FOWLER, M.E., CUBAS, Z.S. (Eds). Biology, medicine and surgery of South American wild animals. Ames: Iowa State University, 2001. p.475-81.

PATTESON, M.W. (Ed). Equine cardiology. Oxford: Blackwell Science, 1996.

PEREIRA, D.M. Efeito da hioscina-nbutilbromida sobre as mensurações ecocardiográficas e os índices ventriculares esquerdos em eqüinos submetidos à sedação com romifidina. 2002. 42f. Dissertação (Mestrado) Faculdade de Ciências Agrárias e Veterinárias, UNESP, Jaboticabal, SP.

PIPERS, F.S., HAMLIN, R.L. Echocardiography in the horse. J. Am. Vet. Med. Assoc., v.70, p.815-819, 1977.

QUEIROZ-NETO, A., ZAMUR, G., GONÇALVES, S.C. et al. Characterization of the antinociceptive and sedative effect of amitraz in horses. J. Vet. Pharmacol. Therap., v.21, p.400-405, 1998.

QUEIROZ-NETO, A.; CARREGARO A.B.; ZAMUR G. et al. Effect of amitraz and xylazine on some physiological variables of horses. Arq. Bras. Med. Vet. Zootec., v.52, p.27-32, 2000.

RAISIS, A.L., YOUNG, L.E., BLISSITT, K.J. et al. A comparison of the hemodynamic effects of isoflurane and halothane anesthesia in horses. Equine Vet. J., v.32, p.318-326, 2000.

RAISIS, A.L., BLISSITT, K.J., HENLEY, W. et al. The effects of halothane and isoflurane on cardiovascular function in laterally recumbent horses. $\mathrm{Br}$. J. Anaesth., v.95, p.317-325, 2005.

REEF, V. B. Evaluation of ventricular septal defects in horses using two-dimensional and Doppler echocardiography. Equine Vet. J. Suppl., v.19, p.86-96, 1995.

SPINOSA, H.S., GORNIAK, S.L., BERNARDI, M.M. (Eds). Farmacologia aplicada a medicina veterinária. 3.ed. Rio de Janeiro: Guanabara Koogan, 2002. p.43-282.

THURMON, J.C., TRANQUILLI, W.J., BENSON, G.J. (Eds). Lumb \& Jone's veterinary anesthesia. 3.ed. Baltimore: Williams \& Wilkins, 1996. p.925.

YOUNG, L.E., SCOTT, G.R. Measurement of cardiac function by transthoracic echocardiography: day to day variability and repeatability in normal Thoroughbred horses. Equine Vet. J., v.30, p.117-122, 1998. 